\title{
Current Situation and Countermeasures of Martial Arts Teaching in Public Physical Education Course of Linyi Vocational College
}

\author{
Decheng Liu \\ ${ }^{1}$ Linyi Vocational College, Linyi, Shandong Province, China
}

\begin{abstract}
Keywords: elective course of martial arts; present situation of teaching; teaching development strategy.
\end{abstract}

\begin{abstract}
In this research, documentary analysis, questionnaire survey, mathematical statistics and other methods are used to study the public martial arts courses in Linyi Vocational College from perspectives of teachers, teaching conditions, teaching contents, teaching materials, students' cognition and school leaders' attention. Through these analyses, it was found that in Linyi Vocational College, teachers of public martial arts are aging; teaching facilities are inadequate; teaching contents cannot meet the requirements of students. These findings help us to choose a better strategy to solve these problems, which plays a very important role in public martial arts teaching in Linyi Vocational College.
\end{abstract}

\section{Introduction}

Nowadays, with the rapid development of economy and culture, attentions on martial arts which come from education departments and the society have been gradually increasing. Martial arts courses have been included in syllabus of college physical education. Martial arts have unique characteristics; they can not only improve the physical health of students, but also cultivate their noble moral characters like self-esteem and self-confidence. [1] These courses also inherit and carry forward the cultural tradition of our Chinese nation. With the reform of physical education in career colleges, the teaching contents and methods of public martial arts have changed greatly. So, what is the actual development situation of public martial arts courses in vocational colleges? What are the problems in the teaching process and how to solve them? This article aims to analyze and study the present situation and existing problems of martial arts teaching in public physical education of Linyi Vocational College, and improve the reform process of public martial arts courses of the school. Researches on this issue are of significant importance. [2]

\section{Research Objects and Research Methods}

Research objects. Students and teachers of public martial arts courses in 2014 are chosen as research objects. There are 500 students and 10 teachers.

Research methods. Documentary method. Through CNKI database, as well as doctor and master thesis database, the author studied articles and journals on elective courses of martial arts. Journals on common required courses in the library were also used to provide theoretical foundation for this paper.

Interview. According to research contents and tasks, the author discussed with some students and teachers of public martial arts class, trying to understand the actual situation of martial arts courses, and provide some reference for this research.

Questionnaire. According to the research purpose, contents and requirements, the author designed two questionnaires for different research objects through referring to questionnaires with similar topics, and following the basic principles of questionnaire design. [3] They are survey questionnaire for teachers of martial arts courses and survey questionnaire for students of martial arts class in Linyi Vocational College. The basic contents of questionnaires include the basic situation of public martial arts courses in Linyi Vocational College, the cognition degree of college students on martial arts, and the attention of school leaders on martial arts. 
Table 1 Questionnaire distribution and collection

\begin{tabular}{llllll}
\hline object & $\begin{array}{l}\text { Questionnaire } \\
\text { distribution }\end{array}$ & $\begin{array}{l}\text { Questionnaire } \\
\text { collection }\end{array}$ & $\begin{array}{l}\text { valid } \\
\text { questionnaire }\end{array}$ & $\begin{array}{l}\text { Recovery } \\
\text { rate }\end{array}$ & $\begin{array}{l}\text { Effective } \\
\text { rate }\end{array}$ \\
\hline teacher & 10 & 10 & 10 & $100 \%$ & $100 \%$ \\
student & 500 & 460 & 455 & $92.00 \%$ & $99 \%$
\end{tabular}

Mathematical statistics. The effective questionnaires were collected, and the data were processed by Excel statistical analysis software.

Logic induction. Data obtained from surveys and analyses were processed through logical induction methods like induction, reasoning, judgment and summary. Finally the conclusion was drawn, and some suggestions were provided.

\section{Results and Analysis}

Current situation of teachers in public martial arts courses. Analysis of the age status of teachers in public martial arts courses.

Table 2 Age status of teachers in public martial arts courses of Linyi Vocational College

\begin{tabular}{lll}
\hline age & Number of people & percentage \\
\hline Younger than 35 & 2 & $20 \%$ \\
$36-45$ years old & 6 & $60 \%$ \\
$46-50$ years old & 1 & $10 \%$ \\
Older than 50 & 1 & $10 \%$
\end{tabular}

The research shows that, among public physical education teachers of Linyi Vocational College, only $20 \%$ teachers are under the age of $35 ; 60 \%$ teachers are between $36-45$ years old; $10 \%$ teachers are between $46-50$ years old; $10 \%$ teachers are older than 50 years old. According to the table, the majority of public martial arts teachers in Linyi Vocational College are above the age of 36, and there are only two teachers who are under the age of 35. The team is facing the difficulty of aging teachers. The advantages of young teachers are energetic, good physical qualities and better demonstrations of actions; while old teachers have more teaching experience and knowledge accumulation. Old teachers ought to cooperate with younger ones to complement each others' advantages, and improve the teaching level.

Analysis of the education background of teachers in public martial arts courses.

Table 3 Education background of teachers in public martial arts courses of Linyi Vocational College

\begin{tabular}{lll}
\hline Education degree & Number of people & percentage \\
\hline junior college & 2 & $20 \%$ \\
bachelor & 6 & $60 \%$ \\
master & 2 & $20 \%$ \\
doctor & 0 & $0 \%$ \\
\hline
\end{tabular}

The research shows that, according to their final educational backgrounds, 2 martial arts teachers have junior college degree; $60 \%$ teachers have bachelor degree; $20 \%$ teachers have master degree; no teacher has doctor degree. It shows that in public physical education of Linyi Vocational College, martial arts teachers have relatively high education degrees, and can complete the teaching tasks with high quality. But no teacher has doctoral degree. The author believes that, teachers should strengthen their studies on professional knowledge, and improve their self-quality to complete teaching tasks better. 
Current situation of martial arts teaching conditions. Teaching conditions have direct influences on teaching quality.

Teaching venues. According to survey of teaching conditions of martial arts courses, the author find that in martial arts classes, all students need to do exercises in the open air of basketball courts or playgrounds. If the weather is not favorable, the class will be cancelled. Due to the inappropriate teaching venues, many martial arts movements cannot be displayed very well, which indirectly lead to the decline of teaching quality.

Teaching equipment .

Table 4 Teaching equipment used in public martial arts courses of Linyi Vocational College

\begin{tabular}{ll}
\hline item & number \\
\hline saber & 285 \\
spears & 110 \\
swords & 120 \\
Cudgel & 100 \\
Target pad & 60
\end{tabular}

The research shows that in martial arts classes of Linyi Vocational College, students are access to many pieces of equipment. There are 285 sabers, 110 spears, 120 swords, 100 cudgels, and 60 target pads. Generally speaking, these equipments are relatively complete, and can meet the needs of students in quantity. But the types of equipment are quite single.

The above data shows that, the teaching conditions of public martial arts courses in Linyi Vocational College should be strengthened. There's no special martial arts gym, and students need to attend classes outside. The protection measures are not perfect in the open air, and students may face dangerous situations. Moreover, the teaching equipments are not perfect. The author holds that, in addition to improve teachers' teaching abilities, teaching venues and equipments also should be improved to improve the teaching quality. [4]

Current situation of martial arts teaching contents.

Table 5 Survey of teaching contents in public martial arts courses of Linyi Vocational College

\begin{tabular}{ll}
\hline course & \multicolumn{1}{c}{ percentage } \\
\hline Primary Changquan & $20 \%$ \\
Primary swordsmanship & $20 \%$ \\
free combat & $8 \%$ \\
Taijiquan & $40 \%$ \\
others & $12 \%$ \\
\hline
\end{tabular}

Table 6 Students' favorite martial arts

\begin{tabular}{ll}
\hline course & percentage \\
\hline Primary Changquan & $8 \%$ \\
Taijiquan & $12 \%$ \\
free combat & $24 \%$ \\
\hline Bodybuilding boxing & $8 \%$ \\
self-defense & $33 \%$ \\
others & $15 \%$ \\
\hline
\end{tabular}

The investigation indicates that, in public martial arts courses of Linyi Vocational College, the proportion of primary Changquan accounts for 20\%; the proportion of primary swordsmanship accounts for $20 \%$; the proportion of free combat accounts for $8 \%$; the proportion of Taijiquan 
accounts for $40 \%$. In addition, $12 \%$ teaching content belongs to other kinds of sports. The above data show that the main teaching contents of public martial arts courses in Linyi Vocational College are primary Changquan and Taijiquan. However, according to table 6, it can be found that students are more interested in self-defense and free combat, which are quite different from the current teaching contents of martial arts courses. The author believes that, the teaching contents of martial arts courses cannot meet students' requirements, and will reduce students' learning enthusiasm. Thus, teaching contents which are more suitable for students should be adopted to improve the teaching quality.

School leaders' attentions on public martial arts courses.

Table 7 Assessment of school leaders' attentions on public martial arts courses

\begin{tabular}{|c|c|c|c|c|}
\hline & \multicolumn{2}{|c|}{ teacher } & \multicolumn{2}{|c|}{ students } \\
\hline & Number & percentage & Number & percentage \\
\hline Much attention & 0 & $0 \%$ & 10 & $2.2 \%$ \\
\hline attention & 2 & $11.1 \%$ & 26 & $5.7 \%$ \\
\hline ordinary & 10 & $55.6 \%$ & 299 & $65 \%$ \\
\hline less attention & 5 & $27.8 \%$ & 120 & $26.1 \%$ \\
\hline No attention & 1 & $5.6 \%$ & 5 & $1.1 \% \%$ \\
\hline total & 18 & 100 & & \\
\hline
\end{tabular}

The research shows that, leaders of Linyi Vocational College do not pay enough attentions to the public martial arts courses. The reasons for these problems are various, and the main reason is that they put mental training above physical training, and do not pay enough attention to physical education courses. [5] The author holds that, leaders of Linyi Vocational College should focus on the all-round development of students and strengthen physical education, especially the martial arts education. It is not only conducive to students, but also carries forward the Chinese traditional culture. [6]

Current situation of teaching evaluation in martial arts courses.

Table 8 Students' teaching evaluation on public martial arts courses

\begin{tabular}{llll}
\hline Evaluation content & percentage & Evaluation method & percentage \\
\hline Attendance & $10 \%$ & Students' self-assessment & 0 \\
skill level & $85 \%$ & peer assessment & 0 \\
effort level & 0 & Teachers' evaluation & $100 \%$ \\
others & 0 & others & 0 \\
\hline
\end{tabular}

From the survey we can find, students' performances are evaluated mainly from their skill levels. Their attendances only account for $10 \%$ of the final scores, which is relatively favorable. But the evaluation contents are not comprehensive enough, and more items should be added in the evaluation system. Students' achievements are all determined by the teacher, which is unreasonable. Peer assessment method should also be included in the evaluation system, which will be conducive to the exchanges between the students, and enhance the unity. Students can find their own shortcomings more easily, and correct them rapidly. [7]

Current situation of martial arts teaching materials. Through the investigation of the teaching materials used in public martial arts courses in Linyi Vocational College, it is found that there's only one textbook used in public martial arts classes, the Chinese National Traditional Sport. The content and form of teaching material are too simple. The author thinks that the teaching materials should be various to attract students. Increasing teaching materials and improving teaching quality can not only improve students' interests in learning and cultivate their conception of lifelong sport, but also conducive to students' characters, and can improve their shortcomings. In that way, students can make greater progress.

Students' cognition on public martial arts courses. 
Table 9 Some students' cognition on public martial arts courses

\begin{tabular}{llll}
\hline cognition degree & percentage & cognitive method & percentage \\
\hline Not familiar & $6 \%$ & acrobatic fighting films & $44 \%$ \\
A little familiar & $55 \%$ & martial arts fictions & $22 \%$ \\
familiar & $32 \%$ & Martial arts books & $23 \%$ \\
Very familiar & $7 \%$ & others & $11 \%$
\end{tabular}

After investigation and study, the author find that in Linyi Vocational College, 6\% students are not familiar with martial arts; 55\% students are a little familiar with martial arts; $32 \%$ students are familiar with martial arts; only 7\% students are very familiar with martial arts. They learn knowledge of martial arts mainly through acrobatic fighting films, novels and books on martial arts. This shows their understanding on martial arts is not enough. In TV programs and novels, martial arts are exaggerated greatly; martial arts in real life are quite different from these artistic expressions. [8] Hence, students may have wrong understanding of martial arts. The research shows that students' cognitive degrees and approaches to martial arts are not advisable, so we need to publicize correct information on martial arts in the school. Only in this way, can we inherit and carry forward the traditional Chinese martial arts. [9]

\section{Conclusions and Suggestions}

Conclusions. In Linyi Vocational College, hardware conditions of martial arts classes like venues and sports equipments are not complete; leaders of the school do not have sports consciousness, and do not pay enough attention to martial arts in physical education. Martial art course cannot play its role in school education. Textbooks used in public martial arts classes are not good enough.

Teachers team of public martial arts classes in Linyi Vocational College is aging, and lacks of highly educated teachers. Teachers' teaching abilities, scientific research levels and professional ethics should be further strengthened. [10]

College students have strong interests in learning martial arts; but their understanding of martial arts is superficial. The teaching contents of martial arts courses cannot match with students' expectations.

Teaching evaluation system is not perfect. The evaluation of students lays too much emphasis on their skill levels, and ignores their learning process.

Leaders of the school do not have sports consciousness, and do not pay enough attention to martial arts in physical education. [11] Martial arts course cannot play its role in school education. Textbooks used in public martial arts classes are not good enough.

Suggestions. Teaching venues and facilities are critical. Students' learning qualities and learning efficiencies are directly related to sports venues and facilities. Therefore, the school authority should also increase investment on martial arts to supplement equipment and build venues. [12]

School leaders should promote the publicity of martial arts, and correct students' understanding of martial arts. Currently, students learn knowledge of martial arts mainly through acrobatic fighting films, novels and books on martial arts. They cannot get comprehensively understanding through these ways. [13] In TV programs and novels, martial arts are exaggerated greatly, and students may have wrong understandings on martial arts. The author suggests school leaders to organize more martial arts activities and martial arts associations to strengthen exchanges between students, and help students to know more about martial arts.

Teaching contents should be made on the basis of practical situations. Students' favorite sports should be included in learning content. The interests of students are the foundation of teaching quality and teaching efficiency. Considering students' ages and psychological characters, self-defense and free combat should be taught in public martial arts classes. [14]

The cultivation of professional qualities of martial arts teachers should be strengthened to improve the teaching and professional levels of martial arts teachers. The teaching and professional levels of 
martial arts teachers directly affect the learning efficiencies of students. [15] Thus, teachers' professional qualities should be strengthened to complete teaching tasks better.

As an indispensable part of teaching, teaching evaluation is key to the improvement of teaching efficiency and quality. Teaching contents and assessment methods should be diversified to promote the communication between students, encourage them to participate in physical exercises, and promote their all-round development.

\section{References}

[1] Y.K. Ni, Transpiration and embarrassment: development dilemma of traditional Chinese sports in contemporary era, J. Sports science. 2005.

[2] Z.Y. Guo, The promotion effects of idea transformation and technology information on the modernization of martial arts, J. Journal of Beijing Sport University. 28 (2005)

[3] Z.J. Teng, Research and Exploration of School Sports, Beijing Sport University Press, Beijing, 2004.

[4] R. Gao, et al., Teaching effects of different teaching materials on martial arts, J. Journal of Physical Education. 5 (2005)

[5] Z.L. Cai, Martial Arts, Higher Education Press, Beijing, 2000.

[6] S.J. Lv, et al., Reform and suggestions of school martial arts courses, J. Journal of Beijing Sport University. 20 (1997)

[7] J.J. Li, The Evaluation of School Physical Education in New Curriculum, Guangdong Higher Education Press, Guangzhou, 2004.

[8] Z.H. Qu, et al., University Sports Curriculum Reform, People's Education Press, Beijing, 2005.

[9] Z.M. Mao, New View of Sports Teaching Reform, Beijing Sport University Press, Beijing, 2005.

[10] W.M. Li, College Physical Education Reform and Development, Tongji University Press, Shanghai, 2003.

[11] Z.J. Guo, Development model of Chinese martial arts, J. Journal of Shanghai University of Sport. $29(2005)$

[12] Z.H. Qu, et al., Introduction to Physical Education Curriculum, People's education press, Beijing, 2005.

[13] X.H. Jin, Current situation and countermeasures of elective Martial arts course in regular institutions of higher learning in Jiangsu province, J. Suzhou University Journal, 28 (2006).

[14] G. Wang, The phenomenon of “cultural siege” in the development of martial arts, J. Journal of Beijing Sport University. 28 (2005).

[15] Research Center on Traditional Ethnic Sports Theory, Shanghai University of Sport, Literary Theory on Martial Arts, People's Education Press, Beijing, 2005. 